University of Nebraska - Lincoln

DigitalCommons@University of Nebraska - Lincoln

Publications, Agencies and Staff of the U.S.

Department of Commerce

U.S. Department of Commerce

2008

\title{
Genetic isolation and morphological divergence of Black Sea bottlenose dolphins
}

Karine A. Viaud-Martineza

San Diego State University

Robert L. Brownell Jr.

Southwest Fisheries Science Center, rlbcetacea@aol.com

Andrew J. Bohonak

San Diego State University

Anastasia Komnenouc

Veterinary Faculty, Aristotle University of Thessaloniki, St. Voutyra 11, 54627 Thessaloniki, Greece

Follow this and additional works at: https://digitalcommons.unl.edu/usdeptcommercepub

Part of the Environmental Sciences Commons

Viaud-Martineza, Karine A.; Brownell, Robert L. Jr.; Bohonak, Andrew J.; and Komnenouc, Anastasia, "Genetic isolation and morphological divergence of Black Sea bottlenose dolphins" (2008). Publications, Agencies and Staff of the U.S. Department of Commerce. 66.

https://digitalcommons.unl.edu/usdeptcommercepub/66

This Article is brought to you for free and open access by the U.S. Department of Commerce at DigitalCommons@University of Nebraska - Lincoln. It has been accepted for inclusion in Publications, Agencies and Staff of the U.S. Department of Commerce by an authorized administrator of DigitalCommons@University of Nebraska - Lincoln. 


\title{
Genetic isolation and morphological divergence of Black Sea bottlenose dolphins
}

\author{
Karine A. Viaud-Martinez ${ }^{a, *}$, Robert L. Brownell Jr. ${ }^{b}$, Anastasia Komnenou, \\ Andrew J. Bohonak ${ }^{a}$ \\ aDepartment of Biology, San Diego State University, 5500 Campanile Drive, San Diego, CA 92182-4614, USA \\ ${ }^{\mathrm{b}}$ Southwest Fisheries Science Center, 1352 Lighthouse Avenue, Pacific Groove, CA 93950, USA \\ ${ }^{\mathrm{c}}$ Veterinary Faculty, Aristotle University of Thessaloniki, St. Voutyra 11, 54627 Thessaloniki, Greece
}

\section{A R T I C L E I N F O}

Article history:

Received 3 April 2007

Received in revised form

26 March 2008

Accepted 7 April 2008

Available online 2 June 2008

Keywords:

Conservation genetics

Gene flow

Mediterranean Sea

Skull shape

Tursiops truncatus

Black Sea

\begin{abstract}
A B S T R A C T
The Black Sea is a semi-enclosed body of water that differs from the adjacent Mediterranean Sea in terms of its biodiversity, oceanographical and ecological characteristics. There is growing international concern about pollution in the Black Sea and other anthropogenic threats to its fauna. The bottlenose dolphin (Tursiops truncatus) is one of three species of cetaceans living in the Azov-Black Sea basin. Despite considerable research on bottlenose dolphins elsewhere, the extent of human impacts on the Black Sea populations is unknown. Previous attempts to award special conservation status to Black Sea cetaceans have failed specifically because policy makers have viewed their ecological and evolutionary uniqueness as equivocal. This study assessed divergence between Black Sea, Mediterranean Sea and Atlantic Ocean bottlenose dolphins for 26 cranial measurements $(n=75$ adult bottlenose dolphin skulls) and mitochondrial DNA ( $n=99$ individuals). Black Sea bottlenose dolphins are smaller than those in the Mediterranean, and possess a uniquely shaped skull. As in a previous study, we found the Black Sea population to be genetically distinct, with relatively low levels of mtDNA diversity. Population genetic models suggest that Black Sea bottlenose dolphins have so little gene flow with the Mediterranean due to historical isolation that they should be managed separately.
\end{abstract}

(c) 2008 Elsevier Ltd. All rights reserved.

\section{Introduction}

Numerous environmental organizations and international protection agencies have expressed concern about increasing pollution and diminishing fish stocks in the Black Sea, and consequential impacts on its faunal assemblage. The Black Sea is a naturally isolated body of water in which three cetacean species are found: the common dolphin Delphinus delphis ponticus, the bottlenose dolphin Tursiops truncatus ponticus, and the harbour porpoise Phocoena phocoena relicta. The full extent of human impacts on these populations, whether or not they are biologically unique, and their degree of isolation are all currently unknown. However, it is clear that overfishing and declining water quality (e.g., increased nutrient loading) have significantly reduced stocks of anchovy (Eugraulis encrasiccolus), horse mackerel (Trachurus mediterraneus), sprat (Sprattus sprattus), and other fish that sustain Black Sea cetaceans (Kideys, 1994; Tuncer et al., 1998). Until the 1980s, dolphin fisheries in the Black Sea killed hundreds of thousands of cetaceans during peak years (e.g., Danilevsky and

\footnotetext{
* Corresponding author: Tel.: +1 8582024765.

E-mail addresses: kviaud@illumina.com (K.A. Viaud-Martinez), Robert.brownell@noaa.gov (R.L. Brownell Jr.), natakomn@vet.auth.gr
} (A. Komnenou), bohonak@sciences.sdsu.edu (A.J. Bohonak). 0006-3207/\$ - see front matter @ 2008 Elsevier Ltd. All rights reserved. doi:10.1016/j.biocon.2008.04.004 
Tuyutyunnikov, 1968; Kleinenberg, 1978; Smith, 1982). Anthropogenic impacts since that time have continued to diminish population sizes (Birkun et al., 1992), including the capture of live Black Sea bottlenose dolphins for aquatic parks.

International conservation organizations have expressed their concerns for the health and status of Black Sea bottlenose dolphins, which are widely recognized as having the smallest population size of the three Black Sea cetaceans (e.g., Tomilin, 1967; Perrin, 1984; Yukhov et al., 1986; Buckland et al., 1992; Birkun, 2002; IWC, 2003; Simmonds, 2003). The Black Sea bottlenose dolphin has been listed as Data Deficient by IUCN since 1996, and a zero annual export quota was established by CITES for live specimens in 2002. The IWC Scientific Committee reviewed the status of these dolphins in 2003 and suggested that Black Sea bottlenose dolphins should be managed as a distinct entity for conservation purposes (IWC, 2003). Nonetheless, protection plans have not yet been implemented due to a lack of quantitative studies on this population. The Agreement on the Conservation of Cetaceans of the Black Sea, Mediterranean Sea and Contiguous Atlantic Area (ACCOBAMS), whose aim is to "reduce threat to cetaceans in Mediterranean and Black Sea waters", has stated that the bottlenose dolphin is "at greater risk of declining and disappearing from the Agreement area" than other cetacean species (Notarbartolo di Sciara and Birkun, 2002), and that an absence of scientific studies on this population impedes the credibility of its proposed conservation measure (ACCOBAMS, 2004, Resolution 2.19). Hence, international agreements that could protect the Black Sea bottlenose dolphin first require demonstration that it is isolated from the adjacent Mediterranean, and that it is evolutionarily unique (CITES Decision 11.91, IUCN, 2000; IWC, 2003; Simmonds, 2003; Reeves et al., 2004).

Bottlenose dolphin morphology has not been quantitatively compared between the Black Sea and adjacent Mediterranean. However, Barabash-Nikiforov $(1940,1960)$ compared Black Sea specimens to published data from distant populations, leading him to suggest a separate Black Sea subspecies: Tursiops truncatus ponticus. Because Kleinenberg (1978) had opposing conclusions, the subspecies designation has not been widely recognized. Recent genetic studies that included 16 Black Sea bottlenose dolphins found relatively low mtDNA gene diversity in the Black Sea, and supported the hypothesis that Black Sea populations are isolated from the Mediterranean (Natoli et al., 2003, 2005). These results were particularly strong for microsatellite data. Tests of mtDNA differentiation between the Black Sea and adjacent areas of the Mediterranean Sea were not statistically significant using $F_{\text {st }}$, although coalescent modeling estimated low levels of gene flow between these populations, and therefore significant divergence. The goals of our study were to jointly analyze morphological and genetic data with sufficiently large sample sizes to test the hypothesis that Black Sea bottlenose dolphins have diverged from the Mediterranean, and to further determine whether this divergence is attributable to historical evolutionary processes or more recent anthropogenic impacts. The results of our study are intended to help clarify the taxonomic status of this population, and facilitate the implementation of conservation plans by agencies such as ACCOBAMS.

\section{Materials and methods}

Genetic material and morphological measurements were collected in cooperation with representatives from nine countries (see Acknowledgements).

\subsection{Individual genotyping}

Tissue samples were collected between 1993 and 2003 from 99 bottlenose dolphins from three basins (Fig. 1): the eastern Atlantic ( $n=25$ from the French and Portugal coasts), the Mediterranean Sea ( $n=31$ from the Liguria/Tyrrhenian Sea, Adriatic Sea, Aegean Sea and Israeli coast) and the Black Sea $(n=43)$. It is likely that very few of these samples represent familial groups, since they were obtained by different agencies through a variety of means (stranded, bycaught, captive) at different times (see Appendix A). Tissue was preserved in $20 \%$ dimethyl sulphoxide saturated with sodium chloride (DMSO) at $-20^{\circ} \mathrm{C}$. DNA was isolated using DNEasy extraction kits (Qiagen). The first 442 base pairs of the mitochondrial DNA (mtDNA) control region were amplified using polymerase chain reaction (PCR) with primers DLTurs-r (5'-CCT GAA GTA AGA ACC AGA TGT CTT ATA AA-3') and DLTurs-f (5'CCA TTC CTC CTA AGA CTC AAG GAA G-3') developed in our laboratory. One $\mu$ l of genomic DNA extraction was added to a $50 \mu \mathrm{l}$ reaction mixture containing $5 \mu \mathrm{l} 10 \times$ Ex Taq buffer (20 mM MgCl2), $2 \mu \mathrm{l} 10 \mu \mathrm{M}$ of each primer, $5 \mu \mathrm{l} 8 \mathrm{mM}$ dNTPs and $0.25 \mu \mathrm{l}$ Ex Taq DNA polymerase (TaKaRa). The PCR thermal profile was $2 \mathrm{~min}$ at $94^{\circ} \mathrm{C}, 35$ cycles of $\left\{30 \mathrm{~s}\right.$ at $94^{\circ} \mathrm{C}$, $30 \mathrm{~s}$ at $60^{\circ} \mathrm{C}, 60 \mathrm{~s}$ at $72{ }^{\circ} \mathrm{C}$, and a final $7 \mathrm{~min}$ at $72^{\circ} \mathrm{C}$. PCR products were purified using GeneClean Turbo kits (Q.BIOgene), cycle sequenced using BigDye v.3.1 (ABI), and sequenced on an ABI 377 sequencer. We aligned sequences by eye using Sequencher 3.1 (Gene Codes Corp.).

\subsection{Population genetic analysis}

Using Arlequin v.2.0 (Schneider et al., 2001), genetic diversity was summarized as the proportion of polymorphic sites $(S)$, haplotype diversity (equivalent to expected heterozygosity, adjusted for population size), and nucleotide diversity $(\pi$; Nei, 1987). Preliminary analyses showed that the genealogical distances among haplotypes were at least somewhat related to their geographic distribution. Therefore, analysis of molecular variance (AMOVA) was used to estimate the degree of subdivision among the seven sites in Fig. 1 as $\Phi_{\text {st }}$, using uncorrected distances among haplotypes (Excoffier et al., 1992). Other mutation models for $\Phi_{\text {st }}$ produced qualitatively similar results. Contingency tests of haplotype distributions (also referred to as "exact tests") were also performed in Arlequin. (Waples and Gaggiotti (2006) found contingency tests to be a relatively powerful method for identifying gene pool boundaries.) Adjacent populations for which subdivision was not significant with either method were pooled and subsequently reanalyzed (see Section 3). The five populations inferred from these analyses consisted of Atlantic (ATL), western Mediterranean (WM), northeastern Mediterranean (NEM), southeastern Mediterranean (SEM) and Black Sea (BS) (Fig. 1).

Genetic patterns of isolation by distance (IBD) were visualized by plotting genetic similarity as a function of geographic 


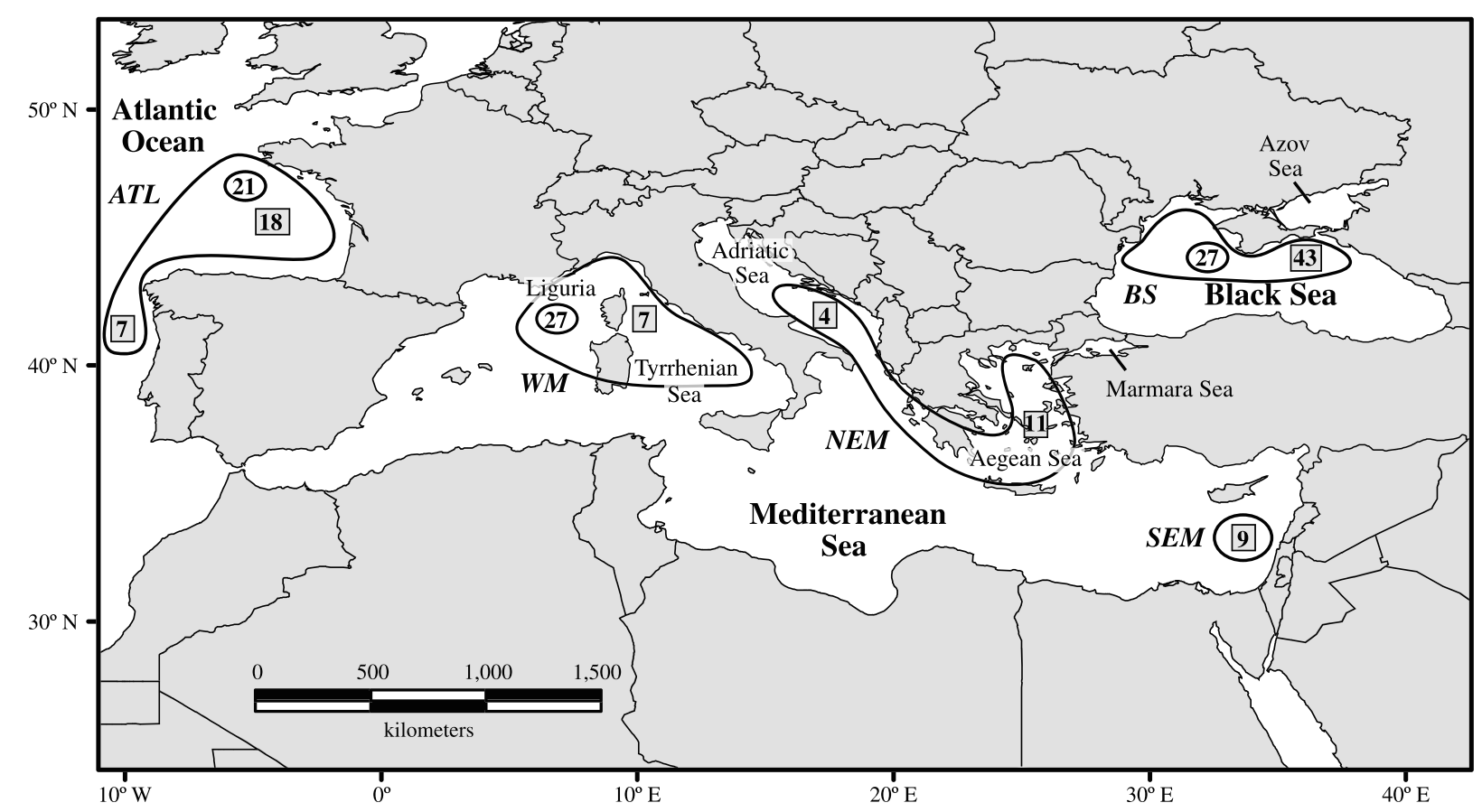

Fig. 1 - Sample sizes across the primary study area. Circled numbers represent the number of skulls measured from each basin. Shaded numbers in squares indicate the sample size at each site for genetic analyses. The large circles represent five designated populations: Atlantic (ATL), western Mediterranean (WM), northeastern Mediterranean (NEM), southeastern Mediterranean (SEM) and Black Sea (BS).

distance for each population pair. Geographic distances (in $\mathrm{km}$ ) were calculated as Euclidean distances between the geographic centers of all individuals sampled in each population. A variety of genetic similarity or distance metrics have been used for IBD analyses, with one or both axes of the IBD scatterplot log-transformed in some cases. We chose the genetic similarity measure $\log \hat{M}=\left(1-F_{\text {st }}\right) / 4 F_{\text {st }}$ as recommended by Slatkin (1993), and calculated $\hat{M}$ from both $F_{\text {st }}$ and $\Phi_{\text {st }}$ for comparison. Preliminary analyses showed that the IBD relationship was most linear and the least biased by outlying points when the variables were not log-transformed. Mantel tests for statistical significance of the IBD relationship were performed using the program "IBD" (Bohonak, 2002).

\subsection{Phylogenetic analyses of haplotypes}

Because the haplotypes were closely related and recently diverged, we estimated their evolutionary relationships using network parsimony reconstruction, implemented in TCS 1.13 (Clement et al., 2000). Network methods tend to perform better than traditional phylogenetic methods when few mutational steps separate recently diverged alleles, and ancestral alleles still persist in the species (reviewed by Posada and Crandall, 2001). To improve phylogenetic accuracy, we included 10 bottlenose dolphins from the Pacific Ocean (Curry, 1997) in the phylogenetic reconstruction, although these were not used in the population genetic analyses described above. Nested sets of relationships (i.e., nested clades) were inferred based on established rules (e.g. Templeton et al., 1987). Geographic associations were assessed for each clade using Geodis 2.5 (Templeton, 1998; Posada et al., 2000; Posada and Templeton, 2005). This approach calculates several geo- graphic association metrics for each clade based on sampling locations for individual dolphins, and the null hypothesis of no geographic association was tested with 100,000 permutations in each case. For clades with statistical significance, evolutionary processes were inferred using the 2005 version of the GeoDis inference key, which suggests likely scenarios regarding gene flow and/or population history. This entire approach, known as nested clade phylogenetic analysis (NCPA) is summarized by Templeton $(1998,2001)$. The final inference key was the focus of criticisms by Knowles and Maddison (2002), which were defended by Templeton, 2004, 2005, 2007. A more recent critique by Panchal and Beaumont (2007) has suggested a higher rate of false positive inferences than previously suggested. In light of this ongoing debate, we consider the NCPA inferences to be working hypotheses, testable and better interpreted using the other frequency- and coalescent-based analyses presented here.

\subsection{Estimation of gene flow, effective population sizes and coalescent time}

The population genetic and phylogenetic analyses suggested historical separation between the Black Sea and the Mediterranean Sea. To estimate both historical and contemporary connectivity between these two areas, we used the "isolation with migration" (IM) model of Hey and Nielsen (2004). This coalescent-based approach estimates the following parameters: (1) the standard population genetic parameter $\theta_{\mathrm{A}}$ for the ancestral population $\left(\theta=4 \mathrm{~N}_{\mathrm{e}} \mu, \mathrm{N}_{\mathrm{e}}=\right.$ effective population size, $\mu=$ mutation rate); (2) the parameter $\theta$ for each of two populations that evolved from the ancestral population (in our analyses, $\theta_{1}$ : Black Sea; $\theta_{2}$ : Mediterranean Sea); (3) $s=$ the 
fraction of the ancestral population that founded the Black Sea; (4) migration rates between populations, $m_{1}$ (from the Mediterranean to the Black Sea) and $m_{2}$ (vice versa), scaled by mutation rate. These parameters can be converted to the average number of migrants per generation $M_{1}$ and $M_{2}$. (5) The time $t$ since the populations diverged, scaled by mutation rate. We analyzed multiple runs of the model to assure parameter convergence, and examined parameter autocorrelations during each run. Models settings were: $>2,000,000$ cycles with a burn-in of 200,000, upper and lower range of the population splitting parameter (s) of 0.1 and 0.5 , inheritance scalar $=0.25$ and HKY mutation model. The range of known mutation rates for marine mammals $(0.5-7 \%$ per My, Hoelzel et al., 1991; Harlin et al., 2003) and a generation time of 22.4 years (Taylor et al., 2007) were used to calculate effective population sizes and divergence time. While this analysis can be run with one marker, results would be more robust based on multiloci (Hey and Nielsen, 2004).

\subsection{Morphological measurements}

We sampled 75 physically mature $T$. truncatus adults from the Black Sea (22 females, 5 males from fisheries bycatch), western Mediterranean ( 9 females, 9 males, 9 unknown) and eastern Atlantic (12 females, 6 males, 4 unknown) for body size and 26 cranial measurements as illustrated in Perrin (1975) (condylobasal length, length of rostrum, rostrum width at base, rostrum width at quarter-length, rostrum width at half-length, rostrum width at 3-quarter-length, width of premaxillaries at half-length, tip of rostrum to external nares, tip of rostrum to internal nares, preorbital width, postorbital width, zygomatic width, width of external nares, maximum width across premaxillaries, parietal width, braincase height, braincase length, length of temporal fossa, height of temporal fossa, length of orbit, length of antorbital process, width of internal nares, length of upper toothrow, length of lower toothrow, length of ramus, height of ramus; see Appendix B for a list of measured specimens). These individuals differed from those used for genetic analyses because teeth were not present on some museum specimens, and permission to sample teeth was not granted for others. Specimens for the morphological analyses could not be located from the northeastern Mediterranean or the southeastern Mediterranean. Measurements were taken on the right side of each skull to avoid redundancy and possible bias due to skull asymmetry (Ness, 1967; Arvy, 1977; Perrin et al., 1994). Physical maturity was judged from the fusion of vertebral epiphyses to the centra, and distal fusion of the maxillae and premaxillae (Perrin and Heyning, 1993; Heyning and Perrin, 1994).

Missing measurements ( $4.4 \%$ of the total data set) were estimated using the expectation maximization (EM) method (Dempster et al., 1977; Strauss et al., 2003) because specimens with missing data are not permissible in PCA and DFA analyses. Missing data are commonly estimated in multivariate morphometric studies with damaged specimens, such as this study (e.g., Rising, 2001; Strauss and Atanassov, 2006), and preliminary analyses with vs. without estimated values showed comparable levels of differentiation among populations. A multivariate analysis of variance (MANOVA) was used to test for morphological divergence among regions and be- tween sexes. Significant results were interpreted with Scheffe post hoc tests. Males and females were pooled together for populations with no sexual dimorphism, and the MANOVA was rerun with the 26 cranial variables. One-way ANOVAs tested for differences among localities in total body length and skull length/body length. A principal component analysis (PCA) was used to standardize the variables; the PCA was performed on direct measurements using the correlation matrix (no factor rotation, extraction parameter: minimum eigenvalue $=0.8$ ). The number of significant multivariate components (PCs) was chosen using the broken-stick method (Frontier, 1976; Jackson, 1993). A multivariate analysis of variance (MANOVA) was used to test whether each component differed among the three localities (Black Sea, Mediterranean Sea and eastern Atlantic). Two discriminant function analyses (DFA) were carried out to identify variables that best discriminate the three regions: a typical DFA based on direct measurements, and a size-free canonical discriminant analysis (Reis et al., 1990). Because DFA adjusts for covariance within groups, each analysis was performed on the covariance matrix of the input data (measurements or residuals) with a tolerance limit for the matrix inversion of 0.001 and forward stepwise variable selection (probability of 0.25 for variable extraction). To find the optimum number of principal components and variables that robustly discriminate populations, additional exploratory PCA and DFA analysis were performed using different types of factor rotation and extraction parameters using SYSTAT, v.10.2 (Systat Software Inc., 2002).

\section{Results}

\subsection{Population genetic structure}

Twenty-six unique mitochondrial haplotypes were found in 99 individuals, and six of these were shared among regions (Table 2, Fig. 2). Twenty-six of 442 sites were polymorphic, with two insertions/deletions, 21 transitions, and three sites with transitions and transversions. Haplotype diversity and nucleotide diversity were similar in the Atlantic, Liguria/Tyrrhenian and Adriatic populations $\left(H_{\mathrm{e}}>0.84, \pi \geqslant 0.01\right)$ but lower in the Black Sea $\left(H_{e}=0.58, \pi=0.003\right)$, the Israeli $\left(H_{e}=0.42\right.$, $\pi=0.002)$ and the Aegean populations $\left(H_{e}=0.65, \pi=0.016\right)$. Only six haplotypes were found in 43 Black Sea individuals, and only three of these were restricted to the Black Sea.

Based on preliminary analyses, we pooled two sites in the eastern Atlantic (AMOVA, d.f. $=98, p>0.05$; exact test $p=0.27$ ), and we pooled the Adriatic and Aegean sites into a "northeastern Mediterranean" population (AMOVA, d.f. =98, $p>0.05$; exact test $p=0.49$ ). The Liguria/Tyrrhenian and the Israeli sites were renamed western Mediterranean (WM) and southeastern Mediterranean (SEM) populations respectively. Differentiation among the five populations defined above (also see Fig. 1) was highly significant and similar using different model of evolution (AMOVA, $\Phi_{\text {st }}=0.48$, d.f. $=98$, overall $p<0.001$; see Table 1). Exact tests of haplotype distributions clearly showed that Black Sea bottlenose dolphins differ genetically from the Mediterranean and Atlantic (Table 1).

Scatterplots of genetic similarity vs. geographical distance was not consistent with a pattern of isolation by distance 


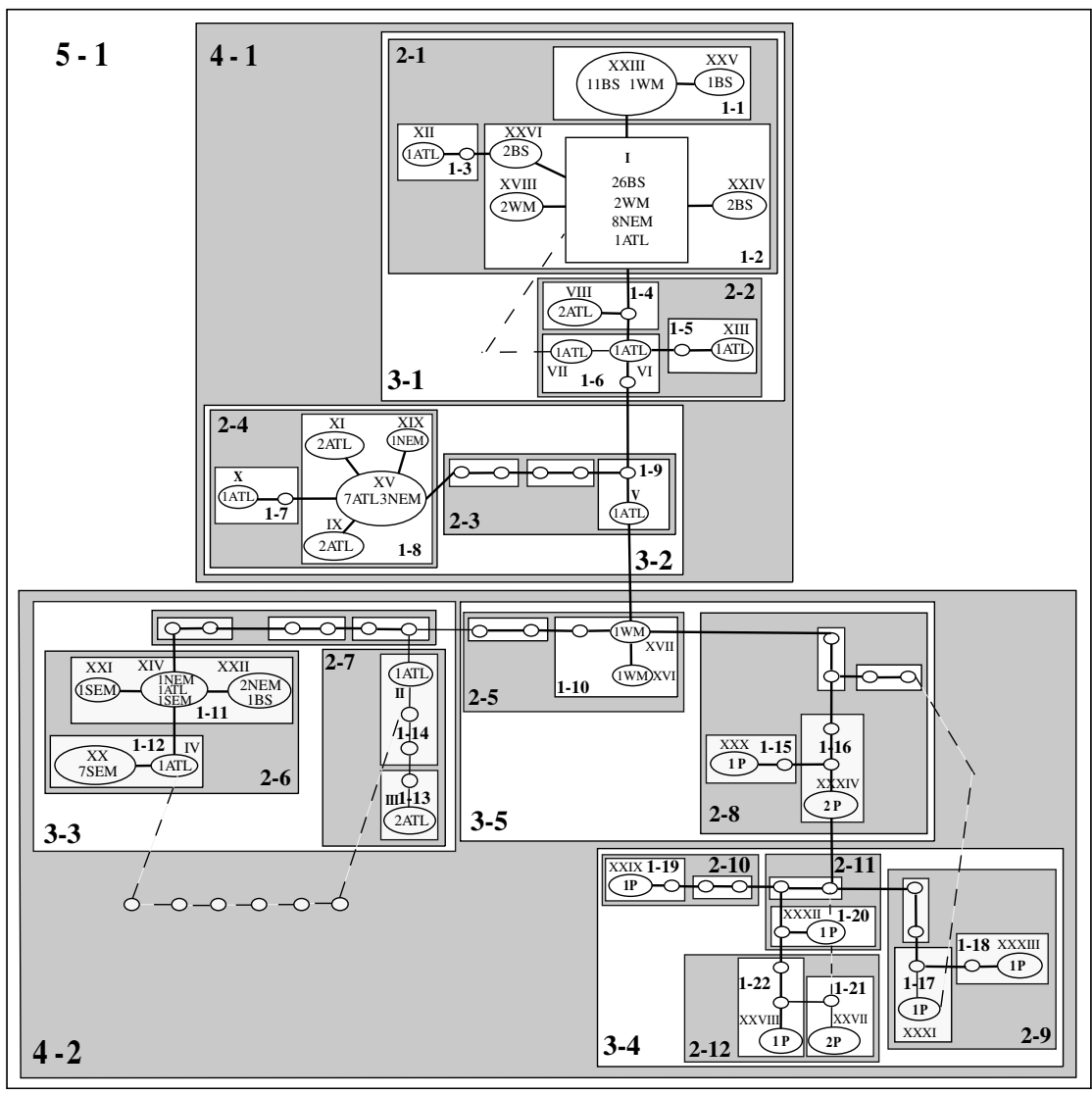

Fig. 2 - Haplotype network for mitochondrial DNA. Population codes are as in Fig. 1, with the addition of samples from the eastern Pacific (P). Oval size is proportional to the number of individuals, which precedes the population code. Each line represents one mutational step, and empty ovals are unsampled haplotypes. Four levels of nesting are enclosed in successively larger boxes. Three ambiguous loops (unresolved portions of the network) were resolved according to the criteria of Crandall et al. (1994) and Templeton et al. (1995).

Table 1 - Genetic differentiation estimated with $\Phi_{\text {st }}$ (above the diagonal) and exact tests ( $p$ values below the diagonal)

\begin{tabular}{lrlclccc} 
Locality & $N$ & ATL & WM & NEM & SEM & BS & Pacific Ocean \\
\hline ATL & 25 & & $0.254^{* *}$ & 0.059 & $0.509^{* *}$ & $0.521^{* *}$ & $0.363^{* *}$ \\
WM & 7 & $0.015 \pm 0.006$ & & 0.084 & $0.809^{* *}$ & $0.191^{*}$ & $0.468^{* *}$ \\
NEM & 15 & $0.006 \pm 0.01$ & $0.029 \pm 0.005$ & & $0.535^{* *}$ & $0.324^{* *}$ & $0.372^{* *}$ \\
SEM & 9 & $<0.001$ & $0.001 \pm 0.001$ & $<0.0001$ & & $0.895^{* *}$ & $0.771^{* *}$ \\
BS & 43 & $<0.0001$ & $0.003 \pm 0.002$ & $<0.0001$ & $<0.0001$ & $0.745^{* *}$ \\
Pacific Ocean & 10 & $<0.001$ & $0.007 \pm 0.002$ & $<0.0001$ & $0.001 \pm 0.0007$ & $<0.0001$ \\
\hline
\end{tabular}

All exact test contrasts are significant at $p<0.05$, and those $\leqslant 0.003$ are significant after Bonferroni correction for 15 tests. ${ }^{*} \Phi_{\text {st }}>0(p<0.05)$, " $\Phi$ st $>0$ ( $p \leqslant 0.003)$. Populations are: Atlantic (ATL), western Mediterranean (WM), northeastern Mediterranean (NEM), southeastern Mediterranean (SEM) and Black Sea (BS). Sample sizes for each population are reported in the second column (N).

(Mantel tests, $p>0.05$ for $\hat{M}$ derived from $F_{\text {st }}$ and for $\hat{M}$ derived from $\Phi_{\text {st }}$; see Fig. 3). This was due primarily to the Israeli dolphins, which were more similar to those from the Atlantic than to the closest population in the Aegean Sea. Excluding the Israeli samples in the western Mediterranean, the IBD plot showed a significant negative slope for $\hat{M}$ derived from $F_{\text {st }}$ (Mantel test, $p<0.001$; Fig. 3 ) but not for $\hat{M}$ derived from $\Phi_{\text {st }}(p>0.05)$. However, the western Mediterranean samples were clear outliers in both analyses. These results suggest that genetic differentiation of Black Sea bottlenose dolphins is due to their geographic isolation, although more detailed conclusions regarding the Israeli population and the exact location of geographic barriers require additional fine-scale sampling.

\subsection{Population history and population parameter estimates}

The mtDNA haplotype network showed moderate to high levels of divergence among populations (Fig. 2). For mtDNA, the Black Sea haplotypes include common ancestral allele I (also found in the Mediterranean), and four closely related alleles (Fig. 2). Ancestral haplotypes found in the Mediterranean and Black Sea in this portion of the network could be due to 
Table 2 - Haplotype affiliations across the five putative populations and 10 samples from the Pacific used for comparison

\begin{tabular}{|c|c|c|c|c|c|c|}
\hline Haplotype & ATL & WM & NEM & SEM & BS & Pacific Ocean \\
\hline I & 1 & 2 & 8 & & 26 & \\
\hline II & 1 & & & & & \\
\hline III & 2 & & & & & \\
\hline IV & 1 & & & & & \\
\hline V & 1 & & & & & \\
\hline VI & 1 & & & & & \\
\hline VII & 1 & & & & & \\
\hline VIII & 2 & & & & & \\
\hline IX & 2 & & & & & \\
\hline $\mathrm{x}$ & 1 & & & & & \\
\hline $\mathrm{XI}$ & 2 & & & & & \\
\hline XII & 1 & & & & & \\
\hline XIII & 1 & & & & & \\
\hline XIV & 1 & & 1 & 1 & & \\
\hline$X V$ & 7 & & 3 & & & \\
\hline XVI & & 1 & & & & \\
\hline XVII & & 1 & & & & \\
\hline XVIII & & 2 & & & & \\
\hline XIX & & & 1 & & & \\
\hline $\mathrm{xx}$ & & & & 7 & & \\
\hline XXI & & & & 1 & & \\
\hline XXII & & & 2 & & 1 & \\
\hline XXIII & & 1 & & & 11 & \\
\hline XXIV & & & & & 2 & \\
\hline $\mathrm{XXV}$ & & & & & 1 & \\
\hline XXVI & & & & & 2 & \\
\hline XXVII & & & & & & 2 \\
\hline XXVIII & & & & & & 1 \\
\hline XXIX & & & & & & 1 \\
\hline $\mathrm{xxx}$ & & & & & & 1 \\
\hline XXXI & & & & & & 1 \\
\hline XXXII & & & & & & 1 \\
\hline XXXIII & & & & & & 1 \\
\hline XXXIV & & & & & & 2 \\
\hline $\mathrm{N}$ & 25 & 7 & 15 & 9 & 43 & 10 \\
\hline
\end{tabular}

Population abbreviations are as in Table 1. Italicized rows represent shared haplotypes among locations.

incomplete lineage sorting (i.e., relatively recent divergence between these areas) or gene flow. However, distantly related

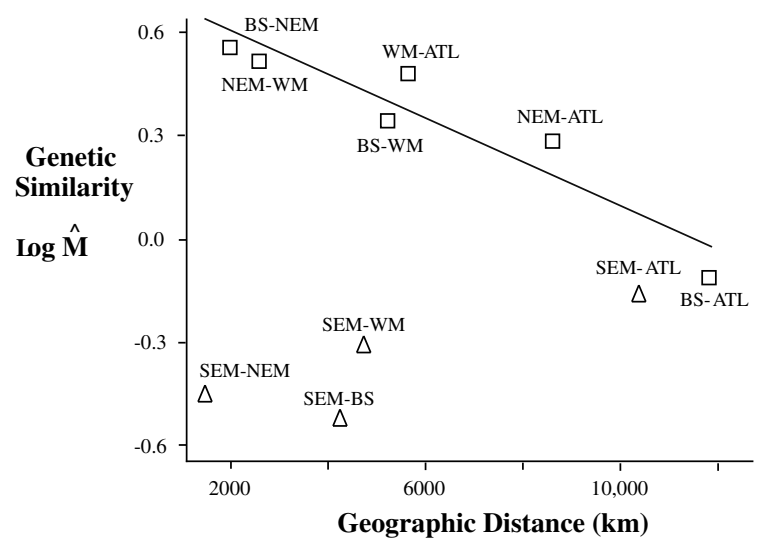

Fig. 3 - "Isolation by distance" plot of genetic similarity vs. geographic distance for all pairs of populations. Triangles represent comparisons with the southeastern

Mediterranean population. The association is statistically significant with the southeastern Mediterranean population excluded $(p<0.001)$. allele XXII was found in two northeastern Mediterranean dolphins and one from the Black Sea. This allele is most parsimoniously interpreted as a rare recent migrant into the Black Sea. Overall, phylogeographic patterns show that the Black Sea and the Mediterranean Sea have been isolated enough in the recent evolutionary past to facilitate significant genetic divergence.

Six clades possessed statistically significant nonrandom geographic associations $(2-1 ; 2-6 ; 3-1 ; 3-3 ; 4-1 ; 4-2)$. The inference key suggested limited gene flow and isolation by distance for clades 2-6 and 4-1, due primarily to partial range overlap among subclades (see Appendix C). For example, within clade 4-1, ancestral clade 3-2 is restricted to the Atlantic and northeast Mediterranean. Its descendent 3-1 has geographical overlap in these areas, but then extends into the Western Mediterranean and Black Sea with clade 2-2 restricted to Atlantic haplotypes (Fig. 2). Clade 3-1 was interpreted as allopatric fragmentation between the Atlantic clade 2-2 and the more broadly distributed clade 2-1. Because clade $3-1$ is necessarily younger than $4-1$, this fragmentation postdates the previous pattern of IBD. The presence of allele XII in an Atlantic specimen is most parsimoniously interpreted as a rare recent migrant back to the Atlantic. Interpre- 
tations of evolutionary process were not possible for clades 21, 3-3 and 4-2 due to insufficient resolution. The NCPA conclusions were generally consistent with the IBD analyses that excluded the Israeli dolphins (see above). Because significant differentiation exists at three successively older levels that involve the Mediterranean Sea and the Atlantic Ocean (2-6, 3-1, 4-1), isolation of the Mediterranean from the Atlantic is not a recent phenomenon.

Fig. 4 shows the posterior distributions for five of the seven parameters estimated with the IM model of divergence between the Black Sea and the Mediterranean Sea populations. These distributions are robust, since multiple independent long runs had identical distributions, and parameter autocor-

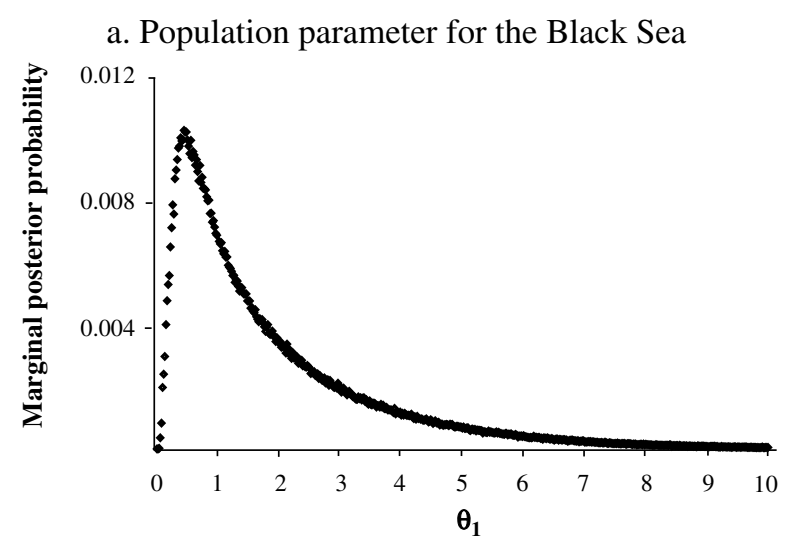

c. Migration parameter, from the Meditterranean

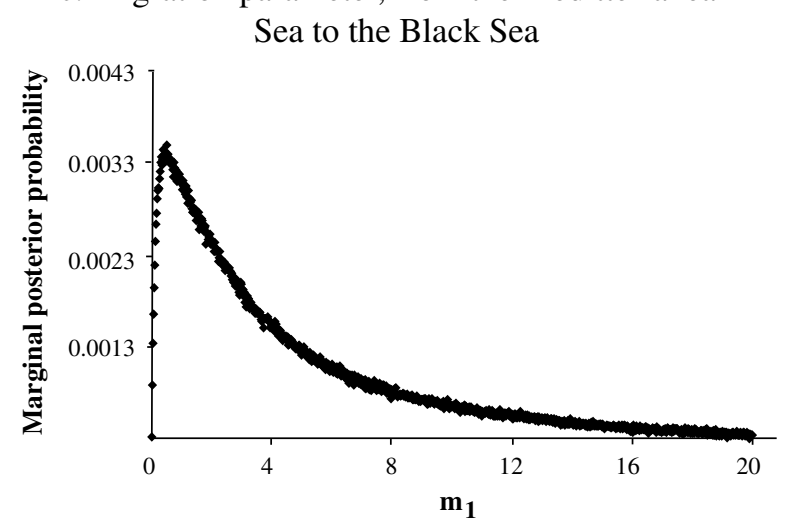

relations decreased rapidly at the beginning of each run. Probability distributions for $\theta_{1}$ and $\theta_{2}$ had clear maxima with maximum likelihood (ML) estimates of $\theta_{1}=0.45$ (95Lo $-95 \mathrm{Hi}$ : 0.21-6.88) for the Black Sea, and $\theta_{2}=21.16$ (11.56-53.58) for the Mediterranean (Fig. $4 \mathrm{a}$ and $\mathrm{b}$ ). Parameters surrounding the ancestral population ( $\theta_{\mathrm{A}}$ and the splitting parameter $s$ ) were poorly resolved and could not be reliably estimated. The parameters $\theta_{1}$ and $\theta_{2}$ can each be translated to recent effective population size $N_{e}$ if the per generation mutation rate $\mu$ is known. Assuming a mutation rate of $\mu=0.5 \%$ per site per million years (Hoelzel et al., 1991) and a generation time estimate of 22.4 years (Taylor et al., 2007), the effective size for the Black Sea population is estimated to be $\mathrm{N} 1=2,273$ individuals

b. Population parameter for the Mediterranean Sea

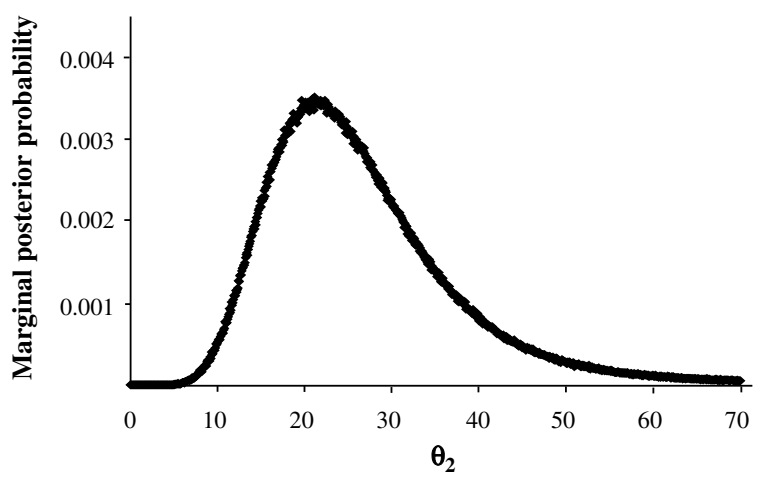

d. Migration parameter, from the Black Sea to the Meditterranean Sea

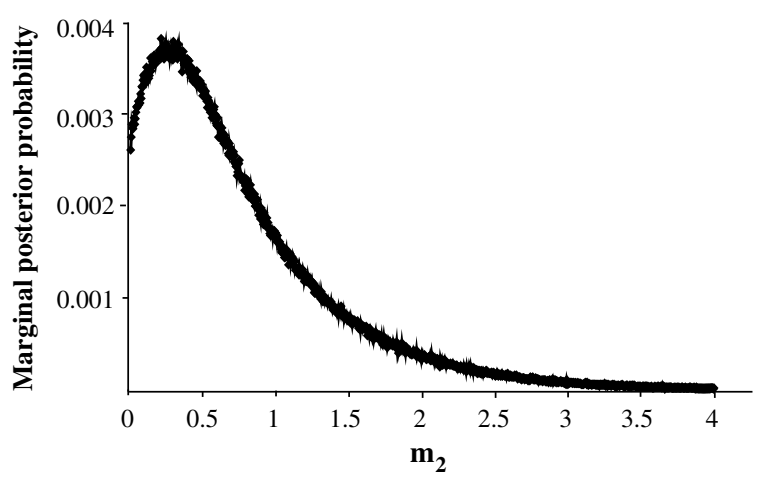

e. Time of founding of the Black Sea

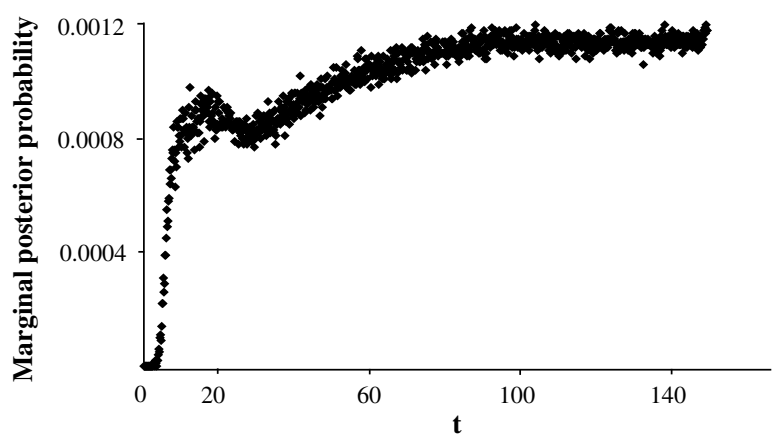

Fig. 4 - Marginal posterior probability distributions for model parameters (scaled by the neutral mutation rate). (a and $b$ ) Population parameters for the Black Sea $\left(\theta_{1}\right)$ and the Mediterranean Sea $\left(\theta_{2}\right)$. (c and d) Migration rates between the Black Sea and the Mediterranean Sea $\left(m_{1}, m_{2}\right)$. (e) Time parameter $(t)$ since population divergence began. 
(95Lo - 95Hi: 1061-34,745 individuals). The Mediterranean population was estimated to be considerably larger, with N2 $=106,860$ individuals (58,379-270,584 individuals). These population size estimates are likely to be high since we used a conservative mutation rate of $0.5 \%$ per $\mathrm{My}$. If this is increased to $7 \%$ per My (Harlin et al., 2003), the maximum likelihood estimate for effective population size decreases to $\mathrm{N} 1=162$ individuals for the Black Sea population (95Lo - 95Hi: 75-2482 individuals) and N2 = 7,669 individuals for the Mediterranean population (4170-19,327). If the actual mutation rate is even higher (see Ho et al., 2007) then the effective population size of bottlenose dolphins in the Black Sea could be even smaller.

Migration parameter $m_{1}$ (from the Mediterranean to the Black Sea) had the highest probabilities for the zero interval and the maximum likelihood estimate of $m_{2}$ (Black Sea to the Mediterranean) was 2.22 individuals per generation or 1.1 female per generation as found in Natoli et al. (2005) (Fig. 4c and d). The Black Sea gene pool has thus been isolated for some time, supporting the NCPA conclusion that the Black Sea population has had low gene flow since it began to diverge from the Mediterranean population.

The likelihood surface for divergence time between the Black Sea and the Mediterranean population had a very low probability for $t=0$, but leveled off and became flat for high values (Fig. 4e). Some amount of historic gene flow with the North Atlantic may have prevented the precise estimation of $t$, as well as the ancestral population parameter size. Ultimately, the distinction between noise and model bias will require the analysis of other genetic markers in parallel (see Carstens and Knowles, 2007).

\subsection{Morphology}

No sexual dimorphism was found in the Atlantic, Mediterranean Sea or Black Sea (MANOVA, d.f. $=62$, all $p$ values in post hoc test $\geqslant 0.05$ ), so males and females were pooled in each population for subsequent analysis. Bottlenose dolphins differed significantly among the Atlantic Ocean, Black Sea, and Mediterranean Sea in terms of total body length (ANOVA, d.f. $=59, p<0.001)$. Bottlenose dolphins were smallest in the Black Sea, with body lengths of $194-244 \mathrm{~cm}$, in contrast to 220-315 cm and 246-320 cm for the Mediterranean and Atlantic respectively. Twenty-five skull measurements differed significantly among regions (MANOVA, d.f. $=74, p<0.001$ ), and Black Sea specimens had the lowest mean value in every case (confirmed with post hoc tests). Only brain case width was not significant $(p \geqslant 0.08)$. Black Sea individuals had a mean skull length of $452.3 \mathrm{~mm}$ (maximum length $=503 \mathrm{~mm}$ ), compared to mean lengths of $520.3 \mathrm{~mm}$ and $537.4 \mathrm{~mm}$ in the Mediterranean and the Atlantic Ocean. Although the Black Sea had the smallest specimens in terms of skull length and body length, the ratio of skull length to body length was proportionally larger in the Black Sea $(20.6 \%$ vs. $19.2 \%$ and $17.8 \%$ for the Mediterranean and Atlantic respectively; ANOVA, d.f. $=54, p<0.001)$.

Principal component analyses with and without rotation were qualitatively similar and resulted in identical biological interpretations. Consequently, we only present the results without rotation. PC1, PC2 and PC3 explained 80.1\%, 4.6\% and $3.5 \%$ of the total variance respectively, and PC1 and PC3 differed significantly among the three seas (MANOVA, d.f. $=74, p<0.001$, Fig. 5a). Correlations between the skull measurements and PC1 were large and positive (loadings $>0.60$ ) with the exception of braincase width (0.12). We therefore interpreted PC1 as a multivariate measure of overall skull size, with high values representing larger skulls. PC2 loaded positively and highly on skull width only (parietal width $=0.95$, $\mid$ all other loadings $\mid<0.30$ ). PC3 loaded positively on width of the external nares and length of orbit ( 0.35 and 0.42 respectively), and negatively on length variables including skull length and rostrum length $(-0.16$ and -0.30$)$. Therefore, PC3 was interpreted as the shape of the orbit and external nares, with high values characterizing dolphins with large orbits and wide external nares, relative to their skull length. Because Black Sea dolphins displayed low PC1 values (mean $=-1.18)$ and PC3 values near zero (mean $=0.17)$, this population has relatively small skulls and a typical shape in terms of PC3.

Discriminant function analysis (DFA) of T. truncatus skull morphometry easily discriminated the Atlantic, Mediterranean, and Black Sea populations (Fig. 5b). Only 13 of 31 vari-
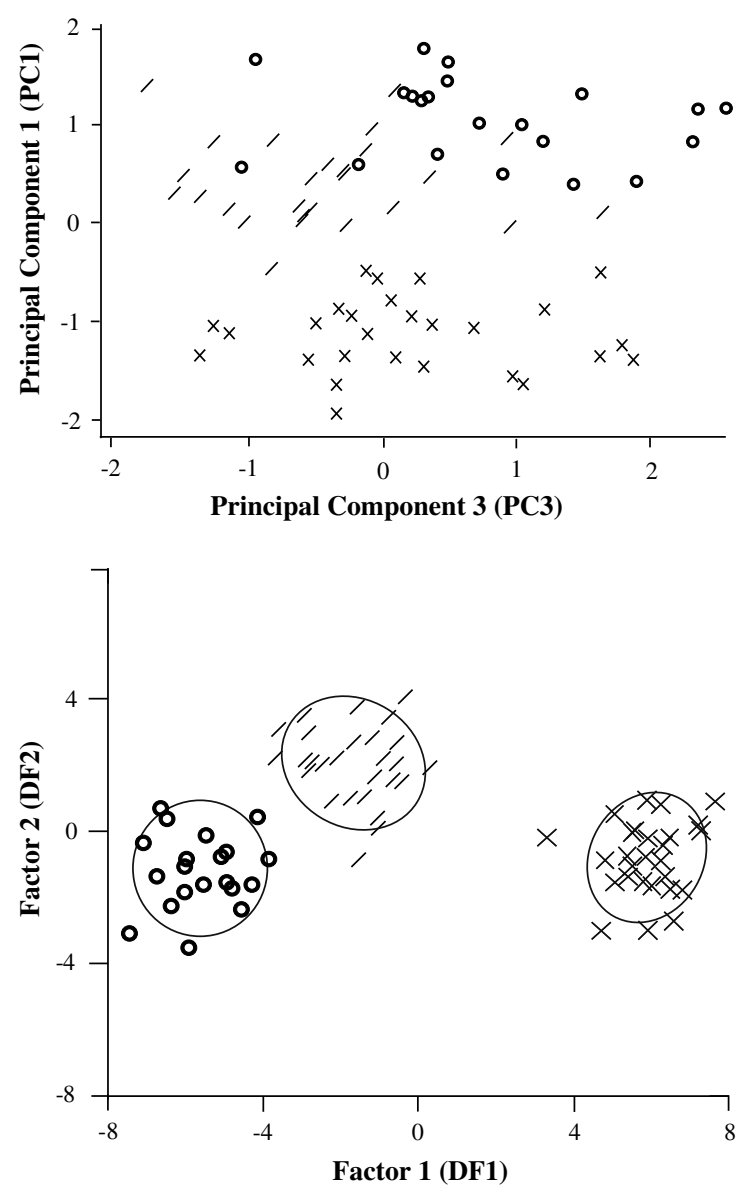

Fig. 5 - Results from multivariate morphological analyses. (a) Scatterplot of principal components 1 and 3. (b) Scatterplot of canonical factors DF1 and DF2. Each point represents an individual from the Black Sea (crosses), Mediterranean Sea (oblique lines) or Atlantic Ocean (circles). 
ables were needed for discrimination, with $100 \%$ classification success (length of rostrum, rostrum width at base, rostrum width at half-length, tip of rostrum to internal nares, postorbital width, width of external nares, maximum width across premaxillaries, parietal width, braincase height, braincase length, length of upper toothrow, length of ramus, height of ramus; Viaud, 2005). In contrast, size-free discriminant analysis resulted in only $50-70 \%$ classification success using various combinations of 13 or more variables. Canonical factors DF1 and DF2 explained $23.1 \%$ and $1.5 \%$ of the total variance in the raw data respectively, and can both be interpreted in terms of skull shape. DF1 loaded positively on postorbital width (0.11) and maximum width of premaxillaries (0.12), and negatively on rostrum width at half-length $(-0.21)$ and ramus length (-0.11). DF2 loaded positively on rostrum length (0.13) and ramus height (0.18), and negatively on rostrum width at the base $(-0.13)$ and the width of the external nares $(-0.10)$. Because Black Sea bottlenose dolphins displayed high DF1 (mean $=5.90$ ) and moderately low DF2 values (mean $=-0.54)$, this population is characterized by large postorbital width and premaxillaries, and by a rostrum that is short relative to the skull length, narrow at the half-length, and relatively wide at the base.

\section{Discussion}

This study demonstrates that Black Sea bottlenose dolphins are genetically and morphologically differentiated from Mediterranean and Atlantic specimens.

\subsection{Gene flow and population history}

Haplotype diversity and nucleotide diversity found in this study for Atlantic and Mediterranean T. truncatus are similar to those in previous Tursiops studies (Curry, 1997; Natoli et al., 2003). Genetic diversity is also lower in the Black Sea than in the Mediterranean and Atlantic, with the exception of the southeastern Mediterranean population.

The genetic data also allow some inferences regarding connectivity and history of the Black Sea. If the Black Sea population was large, completely isolated and ancient, one would expect to see a diverse network of unique Black Sea haplotypes and long branch lengths (comparable to those seen throughout the Mediterranean). In contrast, high gene flow between the Black and Mediterranean Seas either now or in the recent past would lead to multiple shared haplotypes, and no significant population structure. A more complex pattern exists: low genetic diversity in the Black Sea coupled with significant differentiation and some shared haplotypes. A literal interpretation of the theta estimates would suggest that averaged across the genealogy, the Black Sea effective population size is $2 \%$ of that found in the Mediterranean. This could be due to (1) historically smaller population sizes in the Black Sea, and/or (2) largely comparable population sizes, but severe bottlenecks at some point in the Black Sea's history. The inclusion of sequence data from other genes in future studies would increase precision in the coalescent-based analyses, and help to distinguish current vs. past population parameters. Nonetheless, the hypothesis that the Black Sea consis- tently sustains fewer dolphins than the adjacent Mediterranean seems plausible, given the connectivity of the Mediterranean to the Atlantic. However, it is unclear whether the Black Sea has very recently undergone a bottleneck severe enough to cause dramatic losses in genetic diversity. On recent surveys in a restricted portion of the Black Sea, Birkun et al. (2004) obtained an uncorrected abundance estimate of 4193 (2527-6965 - 95\% CI) individuals, leading to the inference that the entire Black Sea contains at least several thousand individuals, and perhaps tens of thousands. After accounting for an effective population size likely to be 11$80 \%$ of the census population (Nunney and Elam, 1994; Frankham, 1995), our upper estimate of $N_{e}$ qualitatively support the numbers reported by Birkun et al. Our lower estimate of $N_{e}=162$ would seem remarkable in this context, but not unprecedented for marine vertebrates with large census population sizes (e.g., Hauser et al., 2002).

Microsatellite markers do not display the skewed frequencies that one would expect from recent, severe bottlenecks in the Black Sea (Natoli et al., 2005), although we note that Natoli et al.'s sample size of $n=16$ may be too low to detect bottlenecks unless they were extremely severe. Nonetheless, the available data suggests that population sizes in the Black Sea are low enough to raise concerns for conservation and management, especially considering that migration rates into the Black Sea are estimated to be only 1-2 individuals per generation. Overall, the simplest conclusion based on all available data is that the Black Sea population has been relatively isolated since its colonization, and that this population may have been historically smaller than the population in the northeastern Mediterranean. It is highly probable that this isolation is now being exacerbated by more recent anthropogenic impacts, such as maritime traffic (Öztürk and Öztürk, 1996, 1997, 2002).

These impacts are not restricted to bottlenose dolphins, as a companion study on the Black Sea harbour porpoise Phocoena phocoena found evidence for very recent decreases in population size (Viaud-Martinez et al., 2007). As with T. truncatus, Black Sea and northern Aegean harbour porpoises are morphologically and genetically unique, suggesting that their nominal subspecies designation is valid. For these reasons, the ACCOBAMS scientific committee recently recommended that the IUCN classify Black Sea/northern Aegean Sea P. phocoena as an endangered sub-species in its Red List (ACCOBAMS, 2006, Report of the SC4).

\subsection{Morphological evolution of Black Sea bottlenose dolphins}

We encountered no Black Sea bottlenose dolphins larger than $244 \mathrm{~cm}$, and such specimens were rarely found in previous studies (e.g., Kleinenberg, 1978: 4/50 > 270 cm; Barabash-Nikiforov, 1940: 3/1450 > $300 \mathrm{~cm}$ ). The smaller body size and relatively large skull of the Black Sea population could be interpreted as an adaptation to coastal environments. Black Sea bottlenose dolphins are confined primarily to the littoral zone of the western-central coast of Turkey, and the northwestern Black Sea where the continental shelf extends 250 km offshore (Kleinenberg, 1978; Sorokin, 1983; Öztürk and Öztürk, 2002). Because the Black Sea is anoxic and 
contains high concentrations of hydrogen sulfide below $200 \mathrm{~m}$ (Sorokin, 1983), deep diving is unlikely to occur. A smaller body may be adaptive for maneuverability in shallow waters, and Black Sea bottlenose dolphins are known to feed on reef fishes such as Black Sea whiting (Merlangius merlangus euxinus), croaker (Sciaena cirrhosa) and scorpionfish (Scorpaena porcus), and benthic fishes including flounder (Bothus maeoticus) (Kleinenberg, 1978). Similar morphological adaptations have been suggested for coastal bottlenose dolphins from the western Atlantic (Hersh and Duffield, 1990; Mead and Potter, 1995) and coastal spinner dolphins in the Gulf of Thailand, the Pacific and southeast Asia (Perrin et al., 1989, 1999). The unique Black Sea T. truncatus skull shape may also represent an adaptation for feeding (sensu Perrin, 1975), since strong, robust rostra are characteristic of coastal, benthic-feeding cetacean ecotypes (e.g. Walker, 1981; Perrin, 1984). Archer (1996) also suggested that wider premaxillaries would strengthen the lateral halves of the rostrum and prevent it from bending. Like for harbour porpoises (Viaud-Martinez et al., 2007), little is known about developmental differences among populations of bottlenose dolphins that could account for the overall smaller size and skull shape differences of those in the Black Sea.

\subsection{Implications for conservation and management}

Conservation and management efforts have become increasingly focused on taxa below the species level (e.g., stocks, evolutionary significant units) in order to better accommodate locally adapted gene pools and protect important ecological and evolutionary processes (e.g. Sherwin et al., 2000; McKay et al., 2005). In the case of the Black Sea bottlenose dolphin, conservation proposals are hampered by the unresolved taxonomic status and the lack of general information on the population status. For example, proposal CoP12Prop3 to CITES to transfer Black Sea bottlenose dolphin from Appendix II (not necessarily threatened with extinction) to Appendix I (threatened with extinction) was not approved in 2002. More recently, ACCOBAMS requested scientific arguments in favor of the establishment of marine protected areas to minimize threats to cetaceans and provide tools to enforce protection of cetaceans in the Black Sea region (ACCOBAMS, 2004, Resolution 2.14). Together with Natoli et al. (2003, 2005), we have demonstrated morphological, genetic, and likely ecological divergence between Black Sea and Mediterranean Sea bottlenose dolphins, sufficient to grant them separate protection and management status. In all likelihood, increased boat traffic in the Marmara Sea will further isolate the Black Sea cetaceans, and anthropogenic impacts such as pollution, diminishing food resources, diseases and physical injuries will continue. Our results support the classification of Black Sea bottlenose dolphins as a separate subspecies, and the original proposal of Tursiops truncatus ponticus Barabash-Nikiforov (1940) would seem to be most appropriate. Our data suggest that the Black Sea population would fit both Mayr's (1942) and Reeves et al.'s (2004) definitions of subspecies, since both morphology and genetics suggest that it is on an independent evolutionary trajectory. Thus, we recommend that urgent actions be taken to assure sustainability of the unique Black Sea population.

\section{Acknowledgements}

The authors are grateful to all who kindly provided samples for genetic analysis and access to skeletal material for measurements: Dr. Holsbeek, Free University of Brussels; Dr. Bompar and Dr. Cesarini, Groupe d'Etude des Cétacés de la Mer Méditerranée; Dr. Beaubrun, Université des Sciences de Montpellier; Mr. Tardy, Laboratoire Méditerranéen de Cétology; Dr. Ridoux, Centre de Recherche sur les Mammifères Marins de La Rochelle; Dr. Robineau, Musée d'Histoire Naturelle de Paris; Dr. Frantzis, Pelagos Cetacean Research Institute; Dr. Komnenou, University of Thessaloniki; A. Scheinin, Dr. Kerem, Dr. Goffman and volunteers, Israeli Marine Mammal Research and Assistance Center; Dr. Podesta, Museo Civico di Storia Narurale di Milano; Dr. Cancelli, Museo Civico di Storia Naturale di Siena, Accademia dei Fisiocritici; Dr. Poggi, Museo Civico di Storia Naturale di Genova; Dr. Affronte, Fondazione Cetacea Onlus; M. Menghini and Dr. Manfrini, Corpo Forestale Dello Stato Stazione di Boscomesola of Codigoro; Dr. Agnelli and Dr. Borri, Zoological Museum La Specola; Dr. Sequeira, Instituto da Conservação da Natureza; Dr. Moldoveanu, National Institute for Marine Research and Development "Grigore Antipa" in Romania; Mrs. Plotoaga and Mrs. Bologa, Complexul Muzeal de Stiinte ale Naturii Constanta; Dr. Pavlinov, Zoological Museum, Moscow State University; Dr. Mukhametov, Severtsov Institute of Ecology and Evolution of the RSA; the National Marine Fisheries Service, SWFSC. We extend our gratitude to Dr. Perrin, Dr. Curry, Dr. O'Corry-Crowe, Dr. LeDuc, Dr. Mesnick, Dr. Galver, Dr. Strauss, Kelly Robertson, Derek Campbell, Milmer Martinez Vergara, Dr. Birkun, Dr. P. Van Klaveren and Dr. M. Van Klaveren, Dr. Palazzoli, and Dr. Gache for their support and expertise. The research was funded by San Diego State University, the Mabel Myers Memorial Scholarship, the SWFSC (who also provided all necessary US import permits) and the J. Covin Memorial Award.

\section{Appendix A. Supplementary data}

Supplementary data associated with this article can be found, in the online version, at doi:10.1016/j.biocon.2008.04.004.

\section{R E F E R E N C E S}

ACCOBAMS, 2004. Report of the second meeting of the parties to ACCOBAMS. <http://www.accobams.org/2006.php/ documents/show/80>.

ACCOBAMS, 2006. Report of the fourth meeting of the scientific committee. <http://www.accobams.org/2006.php/meetings/ documents/4>.

Archer, F.I., 1996. Morphological and genetic variation of striped dolphins (Stenella coeruleoalba). Ph.D. dissertation, University of California, San Diego, USA.

Arvy, L., 1977. Asymmetry in cetaceans. Investigations on Cetacea 8, 161-220.

Barabash-Nikiforov, I.I., 1940. Cetacean fauna of the Black Sea. Its origin and composition. State University of Voronezh, Russia (in Russian).

Barabash-Nikiforov, I.I., 1960. Dimension and coloration of Tursiops truncatus as a criterion of their subspecies 
differentiation. Nauchnye Doklady Vysshei Shkoly Biologicheskie Nauki 1, 35-42 (in Russian).

Birkun, A.A., Jr., 2002. The current status of bottlenose dolphin (Tursiops truncatus) in the Black Sea. Report of the ACCOBAMS First Meeting of the Parties, Monaco, 28 February 2002. Report MOP 1/inf. 8.

Birkun, A.A.J., Krivokhizhin, S.V., Shvatsky, A.B., Miloserdova, N.A., Radygin, G.Y., Nikitina, V.N., Goldin, Y.B., Artov, A.M., Suremkina, A.Y., Zhivkova, Y.P., Plebansky, V.S., 1992. Present status and future of Black Sea dolphins. In: Evans, P.G.H. (Ed.), European Research on Cetaceans 6. ECS, Cambridge, pp. 47-53.

Birkun, A.A., Krivokhizhin, S.V., Glazov, D.M., Shpak, O.V., Zanin, A.V., Mukhametov, L., 2004. Abundance estimates of cetaceans in the coastal waters of the northern Black Sea: results of boat surveys in August-October 2003. In: Belkovich, V.M. (Ed.), Marine Mammals of the Holarctic: Collection of Scientific Papers and the 3rd International Conference (Koktebel, Ukraine, 11-17 October 2004), Moscow, pp. 64-68.

Bohonak, A.J., 2002. IBD (Isolation By Distance): a program for analyses of isolation by distance. Journal of Heredity 93, 153154.

Buckland, S.T., Smith, T.D., Cattanach, K.L., 1992. Status of small cetacean populations in the Black Sea: review of current information and suggestions for future research. Report of the International Whaling Commission 42, pp. 513-516.

Carstens, B.C., Knowles, L., 2007. Shifting distributions and speciation: species divergence during rapid climate change. Molecular Ecology 16, 619-627.

Clement, M., Posada, D., Crandall, K.A., 2000. TCS: a computer program to estimate gene genealogies. Molecular Ecology 9, 1657-1659.

Crandall, K.A., Templeton, A.R., Sing, C.F., 1994. Intraspecific phylogenetics: problems and solutions. In: Scotland, R.W., Siebert, D.J., Williams, D.M. (Eds.), Models in Phylogeny Reconstruction, Systematics Association Special Volume. Clarendon Press, Oxford, England, pp. 273-297.

Curry, B.E., 1997. Phylogenetic relationships among bottlenose dolphins (genus Tursiops) in a worldwide context. Ph.D. Dissertation, Texas A\&M University, TX, USA.

Danilevsky, N.N., Tuyutyunnikov, V.P., 1968. Present state of Black Sea dolphins described. Rybnoye Khozyaystvo 11, 25-27.

Dempster, A.P., Laird, N.M., Rubin, D.B., 1977. Maximum likelihood from incomplete data via the EM algorithm. Journal of the Royal Statistical Society, Series B 39, 1-38.

Excoffier, L., Smouse, P.E., Quattro, J.M., 1992. Analysis of molecular variance inferred from metric distances among DNA haplotypes: application to human mitochondrial DNA data. Genetics 131, 479-491.

Frankham, R., 1995. Conservation genetics. Annual Review of Genetics 29, 305-327.

Frontier, S., 1976. Etude de la décroissance des valeurs propres dans une analyse en composantes principales: comparaison avec le modèle de bâton brisé. Journal of Experimental Marine Biology and Ecology 25, 67-75.

Harlin, A.D., Markowitz, T., Baker, C.S., Wursig, B., Honeycutt, R.L., 2003. Genetic structure, diversity, and historical demography of the New Zealand's dusky dolphin (Lagenorhynchus obscurus). Journal of Mammalogy 84, 702-717.

Hauser, L., Adcock, G.J., Smith, P.J., Bernal Ramirez, J.H., Carvalho, G.R., 2002. Loss of microsatellite diversity and low effective population size in an overexploited population of New Zealand snapper (Pagrus auratus). PNAS 99 (18), 11742-11747.

Hersh, S.L., Duffield, D.A., 1990. Distinction between northwest Atlantic offshore and coastal bottlenose dolphins based on hemoglobin profile and morphometry. In: Leatherwood, S., Reeves, R. (Eds.), The Bottlenose Dolphin. Academic Press, San Diego, CA, pp. 129-139.
Hey, J., Nielsen, R., 2004. Multilocus methods for estimating population sizes, migration rates and divergence time, with applications to the divergence of Drosophila pseudoobscura and D. persimilis. Genetics 167, 747-760.

Heyning, J.E., Perrin, W.F., 1994. Evidence of two species of common dolphins (genus Delphinus) from the Eastern North Pacific. Contribution in Science 442, 1-35.

Ho, S.Y.W., Shapiro, B., Phillips, M.J., Cooper, A., Drummond, A.J., 2007. Evidence for time dependency of molecular rate estimates. Systematic Biology 56 (3), 515-522.

Hoelzel, A.R., Hancock, J.M., Dover, G.A., 1991. Evolution of the cetacean mitochondrial D-loop region. Molecular Biology and Evolution 8, 475-493.

IUCN Species Survival Commission and TRAFFIC Network, 2000. Transfer of Black Sea bottlenose dolphin Tursiops truncatus ponticus from Appendix II to Appendix I. Proponents: Georgia and the United States of America, Doc. No. 11.14. In: IUCN Analyses of Proposals to amend CITES Appendices. IUCN-The World Conservation Union, Gland, Switzerland.

IWC, 2003. Review of status of small cetaceans in the Black Sea. Annex L: Small cetaceans. Report of the scientific committee of the International Whaling Commission 2003. IWC, Cambridge, UK.

Jackson, D.A., 1993. Stopping rules in principal component analysis: a comparison of heuristical and statistical approaches. Ecology 74, 2204-2214.

Kideys, A.E., 1994. Recent dramatic changes in the Black Sea ecosystem: the reason for the sharp decline in the Turkish anchovy fisheries. Journal of Marine Systems 5, 171181.

Kleinenberg, S.E., 1978. Mammals of the Black Sea and the Sea of Azov, results of joint biological-commercial dolphin whaling studies. (English translation from Kleinenberg 1956, by the translation bureau (JA) Multilingual service division, Department of the secretary of state of Canada in 1978 as Fisheries and marine services translation series 4319, 423p). URSS Academy of Science Press, Moscow.

Knowles, L.L., Maddison, W.P., 2002. Statistical phylogeography. Molecular Ecology 11, 2623-2635.

Mayr, E., 1942. Systematics and the Origin of Species. Columbia University Press, New York.

McKay, J.K., Christian, C.E., Harrison, S., Rice, K.J., 2005. "How local is local?" - A review of practical and conceptual issues in the genetics of restoration. Restoration Ecology 13, 432-440.

Mead, J.G., Potter, C.W., 1995. Recognizing two populations of the bottlenose dolphin (Tursiops truncatus) off the Atlantic coast of North America: morphologic and ecologic considerations. IBI Reports 5, pp. 31-44.

Natoli, A., Peddemors, V., Hoelzel, A.R., 2003. Phylogeography and phylogeny of bottlenose dolphins (Tursiops sp.) based on microsatellites and mtDNA analyses. Journal of Evolutionary Biology 17, 363-375.

Natoli, A., Birkun, A., Aguilar, A., Lopez, A., Hoelzel, A.R., 2005. Habitat structure and the dispersal of male and female bottlenose dolphins (Tursiops truncatus). Proceedings of the Royal Society of London Series B: Biological Sciences 272, 1217-1226.

Nei, M., 1987. Molecular Evolutionary Genetics. Columbia University Press, New York.

Ness, A.R., 1967. A measure of asymmetry of the skulls of odontocete whales. Journal of Zoology 153, 209-221.

Nunney, L., Elam, D.R., 1994. Estimating the effective size of conserved populations. Conservation Biology 8, 175-184.

Notarbartolo di Sciara, G., Birkun, A. Jr., 2002. Conservation needs and strategies. In: Notarbartolo di Sciara, G. (Ed.), Cetaceans of the Mediterranean and Black Seas: State of Knowledge and Conservation Strategies. The comprehensive assessment of cetacean status and problems. A report to the ACCOBAMS Secretariat, Monaco, February 2002. Section 18, 21 p. 
Öztürk, B., Öztürk, A.A., 1996. On the biology of the Turkish straits system. Bulletin de l'Institut Océanographique 17, Monaco. CIESM Science Séries 2, Numéro Spéciale 17, pp. 205-217.

Öztürk, B., Öztürk, A.A., 1997. Preliminary study on dolphin occurrence in the Turkish straits system. In: Evans, P.G.H., Parsons, E.C.M., Clark, S.L. (Eds.), European Research on Cetaceans 11. ECS, Kiel, pp. 79-82.

Öztürk, B., Öztürk, A.A., 2002. Status of the cetaceans in the Turkish Black Sea and the Turkish straits system (the Istanbul Strait, Marmara Sea and Canakkale Strait). Report of the International Whaling Commission SC/55/SM2.

Panchal, M., Beaumont, M.A., 2007. The automation and evaluation of Nested clade phylogeographic analysis. Evolution 61 (6), 1466-1480.

Perrin, W.F., 1975. Variation of spotted and spinner porpoise (genus Stenella) in the Eastern Pacific and Hawaii. In: Cos, C.S., Phleger, F.B., Rosenblatt, R.H. (Eds.), . In: Bulletin of the Scripps Institution of Oceanography of the University of California, vol. 21. University of California Press.

Perrin, W.F., 1984. Pattern of geographical variation in small cetaceans. Acta Zoologic Fennica 172, 137-140.

Perrin, W.F., Miyazaki, N., Kasuya, T., 1989. A dwarf form of the spinner dolphin (Stenella longirostris) from Thailand. Marine Mammal Science 5, 213-227.

Perrin, W.F., Heyning, J.E., 1993. Rostral fusion as a criterion of cranial maturity in the common dolphin, Delphinus delphis. Marine Mammal Science 9, 195-197.

Perrin, W.F., Yablokov, A.V., Barlow, J., Mina, M.V., 1994. Comparison of the resolving power of metric and non-metric cranial characters in defining geographical populations of dolphins. Contribution in Science 447, 1-15.

Perrin, W.F., Dolar, M.L., Robineau, D., 1999. Spinner dolphins (Stenella longirostris) of the western Pacific and Southeast Asia: pelagic and shallow-water forms. Marine Mammal Science 15, 1029-1053.

Posada, D., Crandall, K.A., Templeton, A.R., 2000. GeoDis: a program for the cladistic nested analysis of the geographical distribution of genetic haplotypes. Molecular Ecology 9, 487-488.

Posada, D., Crandall, K.A., 2001. Intraspecific gene genealogies: trees grafting into networks. TREE 16, 37-45.

Posada, D., Templeton, A.R., updated November 2005, 2001. Inference key for the nested haplotype tree analysis of geographical distances. <http://darwin.uvigo.es>

Reis, S.F., Pessoa, L.M., Strauss, R., 1990. Application of size-free canonical discriminant analysis to studies of geographic differentiation. Revista Brasileira de Genetica 13, 509-520.

Reeves, R.R., Perrin, W.F., Taylor, B.L., Baker, C.S., Mesnick, S.L., 2004. Report of the workshop on shortcomings of cetacean taxonomy in relation to needs of conservation and management. NOAA Technical Memorandum NMFS, NMFS-SWFSC-363, $94 \mathrm{p}$.

Rising, J.D., 2001. Geographic variation in size and shape of savannah sparrows (Passerculus sandwichensis). Studies in Avian Biology 23, 1-65.

Schneider, S., Roessli, D., Excoffier, L., 2001. Arlequin v. 2.0: A Software for Population Genetic Data Analysis. Genetic and Biometry Laboratory, University of Geneva, Switzerland.

Sherwin, W.B., Timms, P., Wilcken, J., Houlden, B., 2000. Analysis and conservation implications of koala genetics. Conservation Biology 14, 639-649.

Simmonds, M.P., 2003. The Black Sea bottlenose dolphin - What next? Report of the International Whaling Commission SC/55/ SM12.

Slatkin, M., 1993. Isolation by distance in equilibrium and nonequilibrium populations. Evolution 47, 264-279.

Smith, T.D., 1982. Mammals in the Sea. Current understanding of the status of small cetacean populations in the Black Sea. FAO Fisheries Series 5 (4), 121-130.
Sorokin, Y.U.I., 1983. The Black Sea. In: Ketchum, B.H. (Ed.), Ecosystems of the World, Estuaries and Enclosed Seas. Elsevier, New York, USA, pp. 253-292.

Strauss, R.E., Atanassov, M.N., De Oliveira, J.A., 2003. Evaluation of the principal component and expectation maximization methods for estimating missing data in morphometric studies. Journal of Vertebrate Paleontology 23, 284-296.

Strauss, R.E., Atanassov, M.N., 2006. Determining best complete subsets of specimens and characters for multivariate morphometric studies in the presence of large amounts of missing data. Biological Journal of the Linnean Society 88, 309-328.

Systat 10.2., 2002. Computer Software. Systat Software Inc. $<$ http://www.systat.com/>.

Taylor, B.L., Chivers, S.J., Larese, J., Perrin, W.F., 2007. Generation length and percent mature estimates for IUCN assessments of cetaceans. SWFSC Administrative Report LJ-07-01, Southwest Fisheries Science Center, La Jolla, CA, USA.

Templeton, A.R., Boerwinkle, E., Sing, C.F., 1987. A cladistic analysis of phenotypic associations with haplotypes inferred from restriction endonuclease mapping. I. Basic theory and an analysis of alcohol dehydrogenase activity in Drosophila. Genetics 117, 343-351.

Templeton, A.R., Routman, E., Philips, C.A., 1995. Separating population structure from population history: a cladistic analysis of the geographical distribution of mitochondrial DNA haplotypes in the tiger salamander, Ambystoma tigrinum. Genetics 140, 767-782.

Templeton, A.R., 1998. Nested clade analyses of phylogeographic data: testing hypotheses about gene flow and population history. Molecular Ecology 7, 413-418.

Templeton, A.R., 2001. Using phylogeographic analyses of gene trees to test species status and processes. Molecular Ecology 10, 779-791.

Templeton, A.R., 2004. Statistical phylogeography: methods of evaluating and minimizing inference errors. Molecular Ecology 13, 789-809.

Templeton, A.R., 2005. Haplotype trees and modern human origins. Yearbook of Physical Anthropology 48, 33-59.

Templeton, A.R., 2007. Genetics and recent human evolution. Evolution 61, 1507-1519.

Tomilin, A.G., 1967. Mammals of the U.S.S.R and adjacent countries. Cetacea 9 (English translation from Tomilin 1957, by the Israel Program Sci. Transl.). Izdatel'stvo Akademi Nauk SSSR, Moscow, 756pp.

Tuncer, G., Karakas, T., Balkas, T.I., Gökçay, C.F., Aygun, S., Yurteri, C., Tuncel, G., 1998. Land-based sources of pollution along the Black Sea coast of Turkey: concentrations and annual loads of the Black Sea. Marine Pollution Bulletin 36, 409-423.

Viaud, K.A., 2005. Conservation status of the Black Sea bottlenose dolphin (Tursiops truncatus): assessment using morphological and genetic variation. Masters Thesis, San Diego State University San Diego, USA.

Viaud-Martinez, K.A., Martinez Vergara, M., Gol'din, P.E., Ridoux, V., Öztürk, A.A., Öztürk, B., Rosel, P.E., Frantzis, A., Komnenou, A., Bohonak, A.J., 2007. Morphological and genetic differentiation of the Black Sea harbour porpoise (Phocoena phocoena relicta). Marine Ecology Progress Series 338, 281-294.

Walker, W.A., 1981. Geographical variation in morphology and biology of bottlenose dolphins (Tursiops) in the Eastern north Pacific. National Marine Fisheries Service, SWFSC Administrative Report LJ-81-03C.

Waples, R.S., Gaggiotti, O., 2006. What is a population? An empirical evaluation of some genetic methods for identifying the number of gene pools and their degree of connectivity. Molecular Ecology 15, 1419-1439.

Yukhov, V.L., Petukhov, A.G., Korkhov, A.I., 1986. Estimation of the abundance of Black Sea dolphins. Biologiya Morya 12, 64-68. 